IJMS 16 (1), 115-136 (2009)

\title{
LINKING PAY LEVEL TO INTERACTIONAL JUSTICE AS A DETERMINANT OF PERSONAL OUTCOMES
}

\author{
AZMAN ISMAIL \\ Faculty of Cognitive Sciences and Human Development \\ Universiti Malaysia Sarawak \\ MOHD NOOR MOHD SHARIFF \\ College of Business \\ Universiti Utara Malaysia
}

\begin{abstract}
Human resource development literature highlights that pay level is a crucial compensation design issue. The ability of the management to properly design the level of pay according to external and internal organisational factors may have a significant impact on personal outcomes, i.e. job satisfaction, job commitment, and job performance. More importantly, a thorough review of such relationships revealed that effect of pay level on personal outcomes is indirectly affected by feelings of interactional justice. Although the nature of this relationship is interesting, little is known about the influence of interactional justice in compensation programme models. Therefore, this study was conducted to measure the mediating effect of interactional justice in the relationship between pay level and personal outcomes. A survey research method was used to gather 917 usable questionnaires from employees who have worked in Malaysian institutions of higher learning. The outcomes of stepwise regression analysis showed three important findings: firstly, the relationship between interactional justice and pay level would increase job satisfaction. Secondly, the relationship between interactional justice and pay level would increase job commitment. Third, relationship between interactional justice and pay level would increase job performance. This result confirmed that interactional justice does act as a full mediating variable in the pay system model of the organisation sample. In addition, the implications of this study on compensation theory and practice, conceptual and methodological limitations, and directions for future research are discussed.
\end{abstract}

Keywords: Pay level; interactional justice; job satisfaction; job commitment; and job performance. 


\begin{abstract}
ABSTRAK
Literatur pembangunan sumber manusia mengetengahkan bahawa tahap ganjaran adalah penting bagi isu pembentukan pampasan. Kemampuan pengurusan merekabentuk tahap ganjaran yang baik dengan merujuk kepada faktor dalaman dan luaran organisasi boleh memberi kesan signifikan terhadap natijah peribadi seseorang (iaitu, kepuasan kerja, komitmen kerja dan prestasi kerja). Lebih penting lagi, kajian menyeluruh mengenai perhubungan tersebut mempengaruhi kesan terhadap tahap ganjaran terhadap natijah peribadi seseorang dan secara tidak langsung mempengaruhi perasaan terhadap keadilan interaksi. Walaupun perihal perhubungan ini menarik, tetapi sedikit sahaja yang diketahui mengenai pengaruh keadilan interaksi dalam model program pampasan. Oleh itu, kajian ini dijalankan bagi mengukur kesan penyederhana keadilan interaksi dalam perhubungan antara tahap ganjaran dan natijah peribadi seseorang. Kaedah kaji selidik digunakan bagi mengumpul 917 soal selidik daripada pekerja yang bertugas di Institusi Pengajian Tinggi (IPT) di Malaysia. Keputusan pengujian analisis regresi berganda menunjukkan tiga dapatan yang penting: pertama, perhubungan antara keadilan interaksi dan tahap ganjaran telah meningkatkan kepuasan kerja. Kedua, perhubungan antara keadilan interaksi dan tahap ganjaran telah meningkatkan komitmen kerja. Ketiga, perhubungan antara keadilan interaksi dan tahap ganjaran telah meningkat prestasi kerja. Kajian ini mengesahkan bahawa keadilan interaksi memainkan peranan penting sebagai pemboleh ubah penyederhana penuh dalam model sistem ganjaran di persampelan organisasi. Justeru itu, implikasi kajian terhadap teori pampasan dan pekerjaan, limitasi konsepsual dan metodologi, serta cadangan kajian akan datang turut dibincangkan.
\end{abstract}

Kata kunci: Tahap ganjaran; keadilan interaksi; kepuasan kerja; komitmen kerja dan prestasi kerja.

\title{
INTRODUCTION
}

Compensation is a strategic function of the human resource management system. It is often viewed as an employer designing and administering various types of pay systems to reward employee contributions (Heneman, 2002; Milkovich \& Newman, 2008). Traditionally, most employers design pay systems based on internal equity variables whereby the type, level, and amount of pay are allocated to employees based on job structure. This perspective emphasises on pay based on tenure, length of service, seniority, and/or membership and service (Anthony, Perrewe, \& Kacmar, 1996; Milkovich \& Newman, 2008). 
These pay systems are perceived as a Taylorist's product, suitable for manufacturing-based industries operating in stable and predictable business conditions and focusing on organisational tactical objectives as a direction (Anthony et al., 1996; Henderson, 2005). In an era of globalisation, many organisations shift traditional job based pay to that based on organisational strategy and culture. Through this perspective, the fluctuations of pay levels are provided based on merits, knowledge, skills and/or performance (Lawler, 1995, 2000; Milkovich \& Newman, 2008). Although the rules for distributing pay based on performance and job are different, they may be used as complementary to attract, retain, and motivate competent employees to support organisational and human resource management strategies and goals (Anthony et al., 1996; Lawler, 1995, 2000).

\section{PAY LEVEL}

Pay level is a crucial pay design issue where it is often defined as the average of the group of rates which includes a combination of several pay components such as base pay, increases, benefits, allowances, and perquisites (Henderson, 2005; Milkovich \& Newman, 2008). It differs according to jobs in the organisation, jobs in a specific department, or combination of any job types in the organisation for achieving external competitive equity (Anthony et al., 1996; Henderson, 2005). In an era of global competition, many organisations have established pay level policies for the similar and/or different work groups based on the balance between external equity variables (e.g. economic pressures, government policies, laws and regulations, stakeholders and cultures, and customs) and internal equity variables (e.g. corporate strategy, management philosophy, type of job, and level of productivity). Survey and job evaluation methods are often used to assess the significance of such variables, and information gathered from such methods would be used to set up pay level policies for the various types of job categories in organisations (Henderson, 2005; Milkovich \& Newman, 2008).

Most organisations implement three types of pay levels, namely the lead, the match, or the lag policies (Gomez-Mejia, Welbourne, \& Wiseman, 2000; Milkovich \& Newman, 2008). The lead policy is normally set up by an employer to provide higher wages for its employee than the average wage paid by competitors. For example, incentives are often provided as a variable pay when an organisation increases productivity, quality improvements, cost saving and/or profit (Anthony et al., 1996; Milkovich 
\& Newman, 2008). The match policy is often created by an employer to reward wage rates for its employees that matches the wage rates paid by competitors. The lag policy is frequently made by an employer to distribute wage rates lower for its employee than average wages paid in the external market (Henderson, 2005; Milkovich \& Newman, 2008). In practice, some organisations design one form of pay level policy at one time and will shift to another within the same or different occupational families at different times (Anthony et al., 1996; Milkovich \& Newman, 2008). These practices are often done based on the organisations' abilities to pay, and/or interests to remain competitive in their product market. For example, a lead policy is often adopted for critical skill groups, match policy with less critical skills, and lag policy for jobs that are easily filled by the local labour market (Anthony et al., 1996; Lawler, 1995, 2000). Although pay level policies are well designed according to a situational approach, the ability of the management to properly implement such policies may attract, retain and motivate good employees to support organisational strategy and goals (Gomez-Mejia et al., 2000; Milkovich \& Newman, 2008).

Many studies about pay distribution highlighted that pay levels that are adequately allocated to employees who have worked in different jobs, skills, and/or performance may increase positive personal outcomes, such as job satisfaction, job commitment, and job performance (Henderson, 2005; Milkovich \& Newman, 2008). Surprisingly, a further investigation of such relationships revealed that effect of adequacy of pay level on personal outcomes is indirectly affected by perceptions of interactional justice (Adams, 1963, 1965; Bloom, 1999; Mani, 2002; Pfeffer \& Langton, 1993). These findings showed that an individual often observes the capabilities of managers to practise proper treatment in making pay level decisions. If an individual perceives that his/her manager practises appropriate or inappropriate treatment (e.g. showing respect and being accountable) in such decisions, this will strongly invoke his/her feelings of fairness or unfairness to the manager's style, which in turn, would lead to decreased or increased job satisfaction, job commitment, and job performance in organisations (Adams, 1963, 1965; Allen \& White, 2002).

Although numerous studies have been done, little is known about the strength and direction of the mediating role of interactional justice in compensation system models (Robbins, Summers, Miller \& Hendrix, 2000; Skarlicki \& Folger, 1997). Many scholars revealed that interactional justice has been less emphasised in previous studies because research and theoretical development in the field of compensation arise primarily 
from the economic perspective, which emphasises on the design of pay systems as a reaction to market factors of supply and demand (Olson, Schwab, \& Rau, 2000; Ledford \& Hawk, 2000; Rajkumar, 1996). This perspective neglects the influence of human psychological factors, such as interactional justice in affecting the relationship between pay level and personal outcomes (Belcher \& Atkinson, 1987; Belcher, Ferris, \& O’Neill, 1985; Rajkumar, 1996).

Besides that, past research studies have much highlighted the characteristics of pay level policies and neglected a multidisciplinary research approach in compensation management (Belcher \& Atkinson, 1987; Heneman \& Schwab, 1985; Miceli \& Lane, 1991). These conditions fail to capture the dynamic nature of pay system development and decrease the abilities of past research findings to explain how and why pay level affects attitudinal and behavioural outcomes through perceptions of interactional justice in dynamic organisations (Heneman, 2002; Hills, Scott, Markham, \& Vest, 1987; Sturman \& Short, 2000). The discussion has motivated this research to examine the mediating role of interactional justice in the relationship between pay level and personal outcomes that occurs in Malaysian institutions of higher learning. For confidential reasons, the names of individual institutions are kept anonymous.

\section{CONCEPTUAL FRAMEWORK}

The framework of this study is shown in Figure 1, which highlights that effect of pay level on personal outcomes (i.e. job satisfaction, job commitment, and job performance) is indirectly affected by feelings of interactional justice (Bloom, 1999; Mani, 2002; Pfeffer \& Langton, 1993). This finding is consistent with the notion of interactional justice theory (Adams, 1963, 1965; Lawler, 1971; Leventhal, 1980).

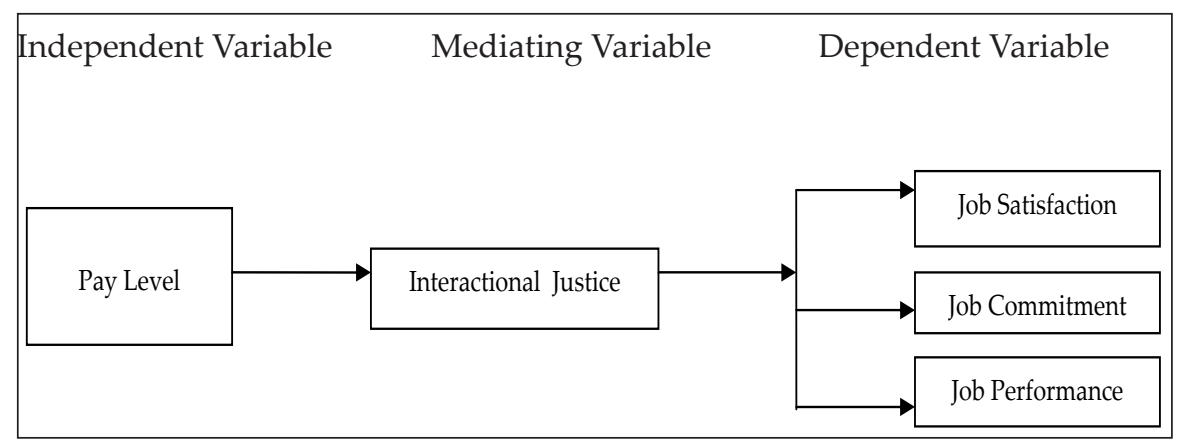

Figure 1: Conceptual framework 


\section{LITERATURE REVIEW AND RESEARCH HYPOTHESIS}

\section{Context of the Study}

Many researchers argued that national socio-cultural differentiations are among the important factors that affect pay system management in organisations (Aryee, 1999; Hofstede, 1991). One dimension of culture that can affect attitudes to pay systems is the concept of individualism and collectivism. Individualism is a value and standard that practises low power distance (e.g. less hierarchy and decentralised decision making) and focus more on individual achievement (e.g. pay for performance and/or merit) (Hofstede, 1991; Sulaiman \& Mamman, 1996). Under an individualistic culture, equitable pays are determined based on an individual's input-output ratio. For example, Americans perceive fair pay as equity (e.g. pay level based on performance) (Gomez-Mejia et al., 2000; Giacobbe-Miller, Miller, \& Victoror, 1998).

Collectivism is a norm and standard that practises large power distance (e.g. more hierarchical structure and centralised decision making) and emphasise more on group interests, co-operation, loyalty, and harmony. Under a collectivistic culture, individuals perceive importance on the same outcome regardless of their contribution. For example, Russians, Japanese, Chinese, and Malaysians perceive fair pay as equality (e.g. pay level based on tenure, seniority, and/or needs) (Aryee, 1999; Money \& Graham, 1999; Sulaiman \& Mamman, 1996).

The literature suggested that pay systems in Malaysian organisations are strongly affected by collectivism culture. For example, the reports of Malaysian royal commission on salary highlighted that the Malaysian public sector has been established as a non-profit organisation where pay levels are determined based on internal equity variables (the rate for different jobs, qualification, and training) and the ability to pay. Whereas, the Malaysian private sector has been established as a business entity where pay levels for their employees are provided based on external competitiveness variables (e.g. profitability) (Aziz Report, 1968; Bain Report, 1956; Benham Report, 1950; Harun Report, 1972; Ibrahim Ali Report, 1975; Mahathir Report, 1976, 1991; Pekeliling Perkhidmatan Bilangan 4 Tahun 2002; Sheikh Abdullah Report, 1972; Suffian Report, 1967; Watson Report, 1963). The scenario shows that pay distribution rules used in Malaysian organisations have influenced the pay system management of Malaysian institutions of higher learning (HL). 
In the HL sector, pay systems are designed and controlled by the stakeholders and administered by the Human Resource Management Departments (HRMDs) of the institutions. The HRMDs use a standardised and centralised approach to ensure equity in determining pay levels to all employees who work in similar and/or different job groups. In terms of pay design, the departments are given little autonomous power to determine pay levels, but they are given flexibilities to use creativity and innovation to administer pay level policies based on procedures formulated by the stakeholders. However the effectiveness of pay level policies is often assessed based on employees' feelings of interactional justice. Based on the information gathered from 15 non-academic and academic staff who participated in the in-depth interviews, the majority of employees often compare their bosses' styles in determining pay levels with other employees who have held the same positions and/or qualifications within the institutions. If employees perceive that their bosses consistently practice equity treatment (e.g. respect employees' opinions, openly discussing performance ratings, and accountable for their decisions) in distributing pay levels (e.g., non-monetary rewards, monetary rewards, and/or both), this will strongly increase their feelings of interactional justice and thus, lead to increased positive attitudes and behaviours (e.g. satisfaction, commitment, and performance). The nature of this relationship is interesting, but the mediating role of interactional justice is neglected because of the paucity of compensation research literature in this country (Ismail, Ismail, \& Sulaiman, 2007; Sulaiman \& Mamman, 1996).

\section{Relationship between Pay Level, Interactional Justice, and Personal Outcomes}

These findings are consistent with several studies conducted in the US university settings. For example, Bloom (1999) conducted a study about pay gap in one university and found that the management decisions to provide higher pay levels to professors who were recently hired by the institution had invoked negative perceptions of professors who were promoted in the institution; this could lead to increased job complaints and dissatisfaction. Besides that, Mani (2002) investigated the pay increase distribution in one university and found that management decisions that neglect performance ratings in distributing pay level had increased higher performers' feelings of unfairness about the systems. As a result, it could lead to decreased commitment to the organisation. Hence, Pfeffer and Langton (1993) examined the wage level differentials in one university and found that the ability of management allocating 
appropriate wage levels to its employee had increased employees' perceptions of justice; this feeling could motivate them to enhance job performance in the organisation.

The compensation research literature has supported the notion of interactional justice theory (Bies \& Shapiro, 1987; Bies, Shapiro, \& Cumming, 1988; Greenberg, 1996, 2003), which stated that an individual is sensitive to the quality of interpersonal treatment that he receives from his managers. If an individual perceives that decision makers (e.g. manager or supervisor) practise fair treatment (e.g. show respect, are accountable, adopt a proper decision-making style, and exhibit communication openness) in determining pay levels, this will strongly invoke employees' feelings of interactional justice. As a result, it may lead to increased positive personal outcomes, especially job satisfaction, job commitment, and job performance (Adams, 1963, 1965; Lawler, 1971; Leventhal, 1980). Based on the above findings, it seems reasonable to assume that fairness of managers' treatment in distributing pay level will influence HL employees as this feeling has been shown to influence US employees. Thus, interactional justice theory further suggested that if HL employees perceive fairness in their managers' treatment in allocating pay levels, this may lead to increased job satisfaction, job commitment, and job performance. Therefore, this study hypothesised that:

H1: Interactional justice positively mediates the effect of pay level on job satisfaction.

$\mathrm{H} 2$ : Interactional justice positively mediates the effect of pay level on job commitment.

H3: $\quad$ Interactional justice positively mediates the effect of pay level on job performance.

\section{METHODOLOGY}

\section{Research Design}

Data for this study were gathered through in-depth interviews, pilot study, and survey questionnaires. In-depth interviews were first conducted with 15 experienced non-academic staff and academic staff in the HL sector. Their views were used to understand the nature of pay level designs, interactional justice practices, personal outcome characteristics, as well as the relationship between such variables in the organisation. This information was used to develop the content of survey questionnaire for a pilot study. Next, a pilot study was conducted on 20 experienced academic and non-academic staff who has worked in 
the HL sector. Their feedback was used to verify the content and format of questionnaires developed for actual survey.

\section{Measures}

Back translation technique was used to translate the content of questionnaires in Malay and English in order to increase the validity and reliability of the instrument (Hulland, 1999; Wright, 1996). The survey questionnaire had three sections. Firstly, pay level consists of three items that were modified from compensation management literature (Adams, 1963, 1965; Lawler, 1995, 2000; Milkovich \& Newman, 2008). The items used to measure this variable were: (1) my reward system reflects my organisation's goals and strategy, (2) my reward system is paid based on my performance and is consistent with my organisation's cultural values, and (3) my perception is that my organisational reward system in my organisation is consistent with best practice.

Secondly, interactional justice had four items that were developed based on organisational justice literature (Jones, Scarpello, \& Bergman, 1999; Leventhal, 1980; Moorman, 1991). The items used to measure this variable were: (1) my immediate boss backs me up when he/she feels I have a valid complaint about my pay, (2) my immediate boss is frank and candid with me about any pay rise, (3) my immediate boss is honest and ethical in dealing with me about my pay issues, and (4) my immediate boss is applies the same standards to everyone when making pay decisions.

Thirdly, job satisfaction was measured using five items that were developed by Warr, Cook, and Wall (1979). The items used to measure this variable were: (1) the amount of responsibility you are given, (2) your opportunity to use your abilities, (3) industrial relations between management and workers in your organisation, (4) the amount of variety in your job, and (5) your job security. Fourthly, job commitment was measured using three of items job commitment developed by Mowday, Steers, and \& Porter (1979). The items used to measure this variable were: (1) I talk up this organisation to my friends as a great organisation to work for, (2) I find that my values and the organisation's values are very similar, and (3) this organisation really inspires the very best in me in the way of job performance.

Finally, job performance was measured using four items that were developed by Lawler and Hall (1970). The items used to measure this variable were: (1) when I do my work well, it gives me a feeling of accomplishment, (2) when I perform my job well, it contributes to my 
personal growth and development, (3) I feel a great sense of personal satisfaction when I do my job well, and (4) doing my job well increases my feelings of self-esteem. These items were measured using a sevenitem scale ranging from "very strongly disagree/dissatisfied" (1) to "very strongly agree/satisfied" (7). Demographic variables were used as a controlling variable because this study focused on employee attitudes.

\section{Sample}

The unit of analysis for this study was employees who have worked in the HL sector. Based on the website of Ministry of Higher Education, Malaysia (Statistik IPTA, 2006), the researchers contacted 100 institutions to obtain official permissions to conduct a survey. Only 21 of the institutions in Peninsular Malaysia agreed to participate in this study. In the first step of data collection procedure, the researchers met the division/department heads in the participating HL institutions to find out about the rules for distributing survey questionnaires in their divisions/departments. While considering the organisational rule, a convenient sampling technique was used to distribute 5000 questionnaires to employees through contact persons (e.g. secretary of department heads, assistant managers, and/ or human resource managers) of the institutions. Of that total, 917 usable questionnaires were returned to the researchers, yielding a $54.5 \%$ response rate. The survey questionnaires were answered by participants based on their consent and on a voluntarily basis. Statistical Package for Social Science (SPSS) version 14.0 was used to analyse the validity and reliability of questionnaire data and test the research hypotheses.

\section{FINDINGS}

\section{Sample Profile}

Table 1 shows that the respondents were $51 \%$ females and $49 \%$ males. Most respondents were aged between 26 to 30 years (30\%). A large number of respondents had a bachelor's degree $(30 \%)$. The majority of respondents were support staff $40 \%$. Most respondents worked in an academic division (70\%). Respondents who had worked less than 2 years $(28 \%)$ were the majority group. The biggest group of respondents served as permanent and confirmed staff $(70 \%)$. The salaries of the majority of respondents were between RM1001 and RM1500 (26\%). Malaysian citizens were the largest respondent group (99\%). Finally, the majority of the respondents $(64 \%)$ were staff who had worked in Malaysian public institutions of higher learning as compared to Malaysian private institutions of higher learning. 
Table 1: Sample Profile (N=917)

\begin{tabular}{|c|c|c|}
\hline Sample Profile & Sub-Profile & Percentage $(\%)$ \\
\hline \multirow[t]{2}{*}{ Gender } & Male & 49 \\
\hline & Female & 51 \\
\hline \multirow[t]{5}{*}{ Age } & $<25$ years & 16 \\
\hline & 26 to 30 years & 30 \\
\hline & 31 to 35 years & 20 \\
\hline & 36 to 40 years & 15 \\
\hline & $>41$ years & 19 \\
\hline \multirow[t]{7}{*}{ Education } & SRP/LCE & 5 \\
\hline & SPM/MCE & 21 \\
\hline & STP/HSC & 4 \\
\hline & Diploma & 17 \\
\hline & Bachelor & 30 \\
\hline & Master & 19 \\
\hline & $\mathrm{PhD}$ & 4 \\
\hline \multirow[t]{6}{*}{ Position } & Professional \& Management Group & 16 \\
\hline & Supporting Group & 40 \\
\hline & Professor & 1 \\
\hline & Associate Professor & 3 \\
\hline & Lecturer & 38 \\
\hline & Assistant Lecturer & 2 \\
\hline \multirow[t]{2}{*}{ Division } & Academic & 70 \\
\hline & Non-Academic & 30 \\
\hline \multirow[t]{6}{*}{ Length of Service } & Less than 2 years & 28 \\
\hline & 3 to 5 years & 27 \\
\hline & 6 to 8 years & 14 \\
\hline & 9 to 11 years & 7 \\
\hline & 12 to 14 years & 6 \\
\hline & More than 15 years & 18 \\
\hline \multirow[t]{4}{*}{ Type of Service } & Permanent \& Confirmed & 70 \\
\hline & Permanent \& Probation & 15 \\
\hline & Contract & 12 \\
\hline & Temporary & 3 \\
\hline \multirow[t]{7}{*}{ Salary (Ringgit) } & $<1000$ & 18 \\
\hline & 1001 to 1500 & 26 \\
\hline & 1501 to 2000 & 20 \\
\hline & 2001 to 2500 & 11 \\
\hline & 2501 to 3000 & 8 \\
\hline & 3001 to 3500 & 7 \\
\hline & $>3501$ & 10 \\
\hline \multirow[t]{2}{*}{ Citizenship } & Malaysian & 99 \\
\hline & Non-Malaysian & 1 \\
\hline \multirow[t]{2}{*}{ Institution } & Public & 64 \\
\hline & Private & 36 \\
\hline
\end{tabular}

Note: SRP/LCE: Sijil Rendah Pelajaran Malaysia/Lower Certificate of Education SPM/MCE: Sijil Pelajaran Malaysia/Malaysia Certificate of Education STP/HSC: Sijil Tinggi Pelajaran/Higher School Certificate 


\section{Validity and Reliability Analyses for Measurement Scales}

The original survey questionnaires consisted of 38 items, which were related to five variables: pay level (7 items), interactional justice (4 items), job satisfaction (14 items), job commitment (7 items), and job performance (6 items). The factor analysis with direct oblimin rotation was done for all variables. Table 2 shows the results of factor analysis process that condensed 38 items into 19 items. The Kaiser-Meyer-Olkin (KMO) and the Bartlett's test of sphericity were conducted for each variable. The $\mathrm{KMO}$ is a measure of sampling adequacy conducted for each variable and the results indicated that it was acceptable. Specifically, these statistical results showed that (1) all research variables exceeded the acceptable standard KMO value of 0.6 , (2) all research variables were significant in Bartlett's test of sphericity, (3) all research variables had eigenvalues larger than $1,(4)$ the items for each research variable exceeded factor loadings of 0.50 (Hair, Anderson, Tatham, \& Black, 1998), and (5) all research variables exceeded the acceptable standard of reliability analysis of 0.70 . This result demonstrates the goodness of data for this study (Nunally \& Bernstein, 1994). These statistical results support the notion of interactional justice theories (Adams, 1963, 1965; Bies \& Shapiro, 1987; Bies et al., 1988; Lawler, 1971; Leventhal, 1980) and findings of previous study (Bloom, 1999; Mani, 2002; Pfeffer \& Langton, 1993), signifying the goodness of data for this study as shown in Table 2.

Table 2: Results of Validity and Reliability Analyses

\begin{tabular}{lccccccc}
\hline \multicolumn{1}{c}{ Measure } & Item & $\begin{array}{c}\text { Factor } \\
\text { Loading }\end{array}$ & KMO & $\begin{array}{c}\text { Bartlett's Test of } \\
\text { Sphericity }\end{array}$ & Eigenvalue & $\begin{array}{c}\text { Variance } \\
\text { Explained }\end{array}$ & $\begin{array}{c}\text { Cronbach } \\
\text { Alpha }\end{array}$ \\
\hline Pay Level & 3 & 0.83 to .88 & 0.73 & $1131.58 ; \mathrm{p}=.000$ & 2.29 & 76.23 & 0.84 \\
$\begin{array}{l}\text { Interactional } \\
\text { Justice }\end{array}$ & 4 & 0.80 to .88 & 0.77 & $2035.92 ; \mathrm{p}=.000$ & 2.92 & 72.99 & 0.88 \\
$\begin{array}{l}\text { Job Satisfac- } \\
\text { tion }\end{array}$ & 5 & 0.59 to .82 & 0.84 & $1447.91 ; \mathrm{p}=.000$ & 2.91 & 58.16 & 0.82 \\
$\begin{array}{l}\text { Job Commit- } \\
\text { ment }\end{array}$ & 3 & 0.54 to .90 & 0.68 & $694.46 ; \mathrm{p}=.000$ & 2.03 & 67.58 & 0.76 \\
$\begin{array}{l}\text { Job Perfor- } \\
\text { mance }\end{array}$ & 4 & 0.83 to .89 & 0.82 & $2346.37 ; \mathrm{p}=.000$ & 3.08 & 76.97 & 0.90 \\
\hline
\end{tabular}

\section{Correlation Analysis and Descriptive Statistics}

Table 3 shows the results of Pearson correlation analysis and descriptive statistics. The means for the variables range from 4.6 to 6.0 , signifying that the levels of pay amount, interactional justice, job satisfaction, job 
commitment, and job performance range from high (4) to highest (7). Pay level positively and significantly correlated with job satisfaction, job commitment, and job performance $(\mathrm{r}=.44, \mathrm{p}=.00 ; \mathrm{r}=.42, \mathrm{p}=.00 ; \mathrm{r}=.30, \mathrm{p}=.00$, respectively), indicating that these variables are important determinants of job satisfaction, job commitment, and job performance. The correlation coefficients for the relationship between the independent variable (i.e. pay level) and the mediating variable (i.e. interactional justice), and the relationship between the independent variable (i.e. pay level) and the dependent variable (i.e. job satisfaction, job commitment, and job performance) were less than 0.90 , indicating the data were not affected by serious collinearity problem (Hair et al., 1998).

Table 3: Correlation Matrix Result for the Research Variable

\begin{tabular}{lccccccc}
\hline \multicolumn{1}{c}{ Variable } & Mean & $\begin{array}{c}\text { Standard } \\
\text { Deviation }\end{array}$ & 1 & 2 & 3 & 4 & 5 \\
\hline Pay Level & 4.6 & 1.4 & $(1)$ & & & & \\
Interactional Justice & 4.6 & 1.4 & $.44^{* *}$ & $(1)$ & & & \\
Job Satisfaction & 5.0 & 1.1 & $.44^{* *}$ & $.46^{* *}$ & $(1)$ & & \\
Job Commitment & 4.8 & 1.2 & $.53^{* *}$ & $.42^{* *}$ & $.55^{* *}$ & $(1)$ & \\
Job Performance & 6.0 & .9 & $.14^{* *}$ & $.18^{* *}$ & $.30^{* *}$ & $.26^{* *}$ & $(1)$ \\
\hline
\end{tabular}

Note: Level of Significance: ${ }^{*} 0.50 ; ;^{* *} 0.01 ;{ }^{* * *} 0.001$

Reliability Estimation in the Parenthesis (1)

\section{Outcomes of Testing Mediating Model}

Stepwise regression analysis was recommended to assess the magnitude and direction of each independent variable, and vary the mediating variable in the relationship between many independent variables and one dependent variable (Foster, Stine, \& Waterman, 1998). Baron and Kenny (1986) suggested that a mediating variable can be considered when it meets three conditions: firstly, the predictor variables are significantly correlated with the hypothesised mediator. Secondly, the predictor and mediator variables are all significantly correlated with the dependent variable. Thirdly, a previously significant effect of predictor variables is reduced to non-significance or reduced in terms of effect size after the inclusion of mediator variables into the analysis (Wong, Hui, \& Law, 1995). In this regression analysis, standardised coefficients (standardised beta) were used for all analyses (Jaccard, Turrisi, \& Wan, 1990). Table 4 shows that the outcomes of testing the hypotheses using stepwise regression analysis. 


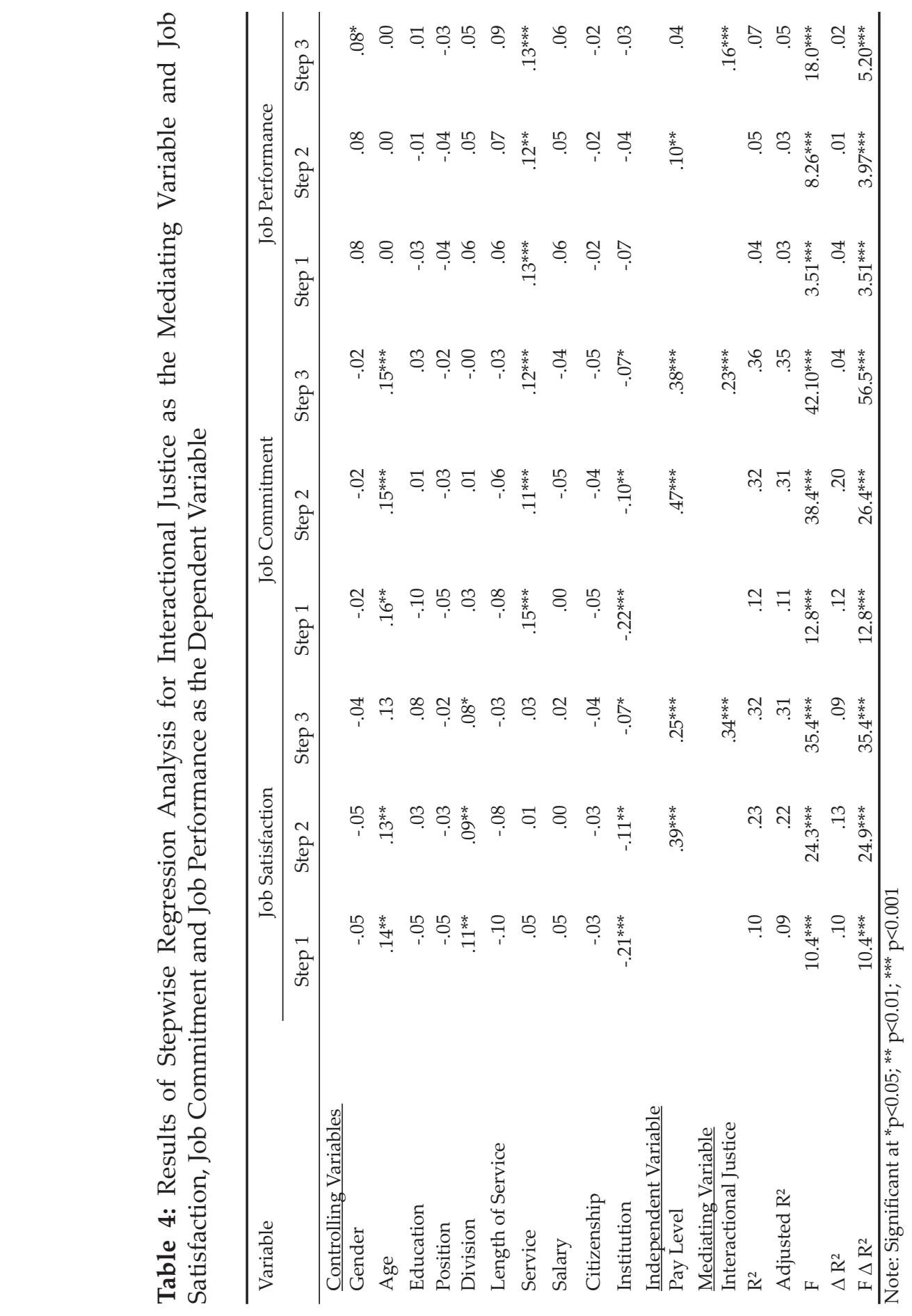

128 IJMS 16 (1), 115-136 (2009) 
The results of testing hypothesis are summarised in Step 3 of the table. Firstly, the relationship between interactional justice and pay level significantly correlates with job satisfaction $(\beta=.34, \mathrm{p}>0.000)$, therefore H1 was supported. This relationship explained that the significant relationship between pay level and job satisfaction in Step $2(\beta=.39$, $\mathrm{p}<0.000)$ did not change to non-significance in Step $3(\beta=.25, \mathrm{p}<0.000)$ when interactional justice is entered in the analysis. However, the strength of such relationships was decreased in Step 3. This result confirms the mediating role of interactional justice in the relationship between pay level and job satisfaction.

Secondly, the relationship between interactional justice and pay level significantly correlates with job commitment $(\beta=.23, \mathrm{p}<0.000)$, therefore $\mathrm{H} 2$ was supported. This relationship explained that the significant relationship between pay level and job commitment in Step $2(\beta=.47$, $\mathrm{p}=.000)$ did not change to non-significance in Step $3(\beta=.38, \mathrm{p}=.000)$ when interactional justice is included in the analysis. However, the strength of such relationship was decreased in Step 3. This result confirms the mediating role of interactional justice in the relationship between pay level and job commitment.

Finally, the relationship between interactional justice and pay level significantly correlates with job performance $(\beta=.16, \mathrm{p}<0.000)$, therefore H3 was supported. This relationship explained that the significant relationship between pay level and job performance in Step $2(\beta=.10$, $\mathrm{p}<0.00)$ had changed to non-significance in Step $3(\beta=.04, \mathrm{p}<0.05)$ when interactional justice is included in the analysis. This result confirms the mediating role of interactional justice in the relationship between pay level and job performance. Thus, the results of testing the mediating model confirmed that interactional justice does act as a full mediating variable in pay level and personal outcomes in the HL sector sample.

\section{DISCUSION AND IMPLICATIONS}

The findings of this study confirmed that interactional justice does act as a full mediating variable in the pay system models of the HL sector. In the sector, HR managers and/or managers use the policy and procedures formulated by the stakeholders to distribute pay levels to all employees. In terms of employees' perspective, the majority of employees perceive that employers have provided higher pay levels based on their contributions. Employees perceive that HR managers are able to 
use proper treatment in determining pay levels, and this has invoked their feelings of justice about the managerial' styles. When employees' feelings of interactional justice are high, this may lead to increased job satisfaction, job commitment, and job performance in the HL sector. The implications of this study can be divided into three major aspects: theoretical contribution, robustness of research methodology, and practical contribution. In terms of theoretical contribution, the findings of this study advocated that the effect of pay level on personal outcomes (i.e., job satisfaction, job commitment, and job performance) is indirectly influenced by feelings of interactional justice. This result was strongly supported by studies done by Bloom (1999), Mani (2002) and Pfeffer and Langton (1993). These findings have extended previous research conducted in most Western countries and provided great potential to understand the notion of interactional justice in the HL sector pay level model.

Regarding the robustness of research methodology, the data gathered from compensation management literature, the in-depth interviews, and the survey questionnaire have satisfactorily met the requirements of validity and reliability, and this can lead to the production of accurate and reliable findings. With respect to practical contributions, the findings of this study may be used as guidelines by HR practitioners to improve the design and administration of pay level policies in organisations. Firstly, the level of pay needs to be designed based on multiple criteria (such as job, performance, needs and/or competitor's pay) to appreciate employee contributions in the workplace. Secondly, adequacy of monetary rewards (e.g. salary and bonus) and non-monetary rewards (e.g. leave, health care, official work claims, loan, and retirement awards) need be adjusted according to current external and internal organisational changes. This adjustment can help employees to meet basic needs, as well as improve standard of living and status in society. Thirdly, the contents and methods of compensation training programme need to be renewed according to current organisational changes, and this may increase the capabilities of HR managers and/or managers to design creative pay plans, properly use pay distribution rules, as well as manage employee attitudes toward pay systems. Finally, human resource policies need to focus on recruiting knowledgeable and experienced employees in labour and employment laws, and this may decrease malpractices in implementing pay policies and procedures in organisations. Considering such suggestions will invoke employees' feelings of justice to the managers' styles in making pay decisions, and this may lead to increased positive subsequent personal outcomes in organisations. 


\section{LIMITATIONS}

The conclusion drawn from the results of this study should consider the limitations below. Firstly, a cross-sectional research method could not capture the developmental issues (e.g. intra-individual change and restrictions of making inference to participants) and/or causal connections between variables of interest. Secondly, this study only examined the relationship between latent variables, and the conclusion drawn from this study does not specify the relationship between specific indicators for the independent variable, mediating variable, and dependent variable. Thirdly, the outcomes of multiple stepwise regression analysis had focused on the level of performance variation explained by the regression equations (Tabachnick \& Fidell, 2001), whereas there are still a number of unexplained factors that need to be incorporated to identify the causal relationship among variables and their relative explanatory power. Finally, the sample for this study was taken from one industry (i.e. educational) sector that allowed the researchers to gather data via survey questionnaires. These limitations may decrease the ability to generalise the findings of this study to other industry settings.

\section{SUGGESTIONS FOR FUTURE RESEARCH}

Directions for future research should consider the conceptual and methodological limitations of this study. Firstly, several organisational (e.g. type, ownership, and size) and personal (e.g. gender, length of service, and salary) characteristics should be further explored, and this may provide meaningful perspectives for understanding of how individual similarities and differences affect pay level policies. Secondly, the limitations of cross-sectional research method may be overcome if longitudinal studies are used to collect data, and describe the patterns of change and the direction and magnitude of causal relationships between variables of interest. Thirdly, the effect of pay level policies on personal outcomes via its impact upon feelings of interactional justice can be clearly understood if more organisational sectors are used as a pay referent. Fourthly, other theoretical constructs of organisational justice theory, such as procedural justice and distributive justice need to be considered because they have widely been recognised as an important hub that links pay level policies to personal outcomes (Greenberg, 1996 \& 2003; Heneman, 2002; Skarlicki \& Folger, 1997). Finally, other personal outcomes of interactional justice such as job turnover, ethnicity, and deviant behaviours need to be included in future research (Greenberg, 
1996 \& 2003; Robbins et al., 2000). The importance of these issues needs to be further discussed in future research.

\section{CONCLUSION}

This study confirmed that interactional justice does act a mediating role in the pay system models of the studied organisations. This result has also broadened and supported compensation research literature mostly published in Western countries. Therefore, current research and practice within the pay system models needs to consider perceptions of interactional justice as a critical aspect of the pay level. This study further suggested that HR managers and/or managers should be trained to practise good treatment (e.g. show respect and accountability) in making pay decisions. The ability of HR managers and/or managers to practise such treatments will strongly invoke employees' feelings of interactional justice. As a result, it may lead to increased positive attitudinal and behavioural outcomes. Thus, such positive outcomes may lead employees to maintain and sustain organisational competitiveness in the global economy.

\section{REFERENCES}

Adams, J.S. (1963). Towards an understanding of inequity. Journal of Abnormal and Social Psychology, 67, 422-436.

Adams, J.S. (1965). Inequity in social exchange. In L. Berkowitz (Ed.). Advances in Experimental Social Psychology, 2, (pp. 267-299). New York: Academic Press.

Allen, R.S., \& White, C.S. (2002). Equity sensitivity theory: A test of responses of two types of under-reward situations. Journal of Managerial Issues, 14(4), 435-152.

Anthony, W.P., Perrewe, P.L., \& Kacmar, K.M. (1996). Strategic human resource management. New York: Harcourt Brace.

Aryee, S. (1999). An examination of the moderating influence of breadwinner role salience on the pay-life satisfaction relationship. Human Relations, 52(10), 1279-1290.

Aziz Report. (1968). Report of the Royal Commission on the teaching services, West Malaysia. Unpublished Report, Public Services Department, Malaysia.

Bain Report. (1956). Report of the commission on public services of the governments of Sarawak, North Borneo and Brunei, Unpublished Report, Public Services Department, Malaysia. 
Baron, R.M., \& Kenny, D.A. (1986). The moderator-mediator variable distinction in social psychological research: Conceptual, strategic, and statistical considerations. Journal of Personality and Social Psychology, 51(6), 1173-1182.

Belcher, D.W., \& Atkinson, T. (1987). Compensation administration. Englewood Cliffs, NJ: Prentice Hall.

Belcher, D.W., Ferris, N.B., \& O'Neill, J. (1985). How wage surveys are being used. Compensation and Benefits Review, 17(4), 34-51.

Benham Report. (1950). Report of the special committee on salaries in the Federation of Malaya. Unpublished Report, Public Services Department, Malaysia.

Bies, R.J., \& Shapiro. D.L. (1987). Interactional fairness judgements: The influence of causal accounts. Social Justice Research, 1, 1999-218.

Bies, R.J., Shapiro, D.L., \& Cummings, L.L. (1988). Causal accounts and managing organizational conflict: Is it enough to say it's not fault? Communication Research, 15, 381-399.

Bloom, M. (1999). The performance effects of pay dispersion on individuals and organizations. Academy of Management Journal, 42(1), 25-40.

Foster, D.P., Stine, B., \& Waterman, R. (1998). Business analysis using regression: A casebook. Place: Springer-Verlag.

Gomez-Mejia, L.R., Welbourne, T.M., \& Wiseman, R.M. (2000). The role of risk sharing and risk taking under gainsharing. The Academic of Management Review, 25(3), 492-507.

Giacobbe-Miller, J.K., Miller, D.J., \& Victorov, V.I. (1998). A comparison of Russian and U.S. pay allocation decisions, distributive justice judgements, and productivity under different payment conditions. Personnel Psychology, 51(1), 137-364.

Greenberg, J. (1996). The quest for justice on the job: Essays and experiments. Thousand Oaks, CA: Sage.

Greenberg, J. (2003). Creating unfairness by mandating fair procedures: The hidden words of a pay-for-performance plan. Human Resource Management Review, 13, 41-57.

Hair, J.F., Anderson, R.E., Tatham, R.L., \& Black, W.C. (1998). Multivariate data analysis. New Jersey: Prentice-Hall International.

Harun Report. (1972). Report of the Royal Commission on the remunerations and conditions of service in local authorities and statutory authorities. Unpublished Report, Public Services Department, Malaysia.

Henderson, R.I. (2005). Compensation management in a knowledge basedworld. New Jersey: Prentice-Hall. 
Heneman, H.G. (2002). Compensation research directions and suggestions for the new millennium. Human Resource Management Review, 12, 75-80.

Heneman, H.G., \& Schwab, D.P. (1985). Pay satisfaction multidimensional nature and measurement. International Journal of Psychology, 20, 129141.

Hills, F., Scott, D., Markham, S., \& Vest, M. (1987). Merit pay: Just or unjust desserts. Personnel Administrator, 32, 53-64.

Hofstede, G. (1991). Cultures and organisations: Software of the Mind. New York: McGraw-Hill.

Hulland, J. (1999). Use of partial least square (PLS) in strategic management research: A review of four recent studies. Strategic Management Journal, 20(2), 195-204.

Ibrahim Ali Report. (1975). Revised report of the royal salaries Commission. Unpublished Report, Public Services Department, Malaysia.

Ismail, A., Ismail, Y., \& Sulaiman, M. (2007). Distributive justice, pay structure, and attitudes and behaviour: A case of Malaysian public institutions of higher learning. Proceedings of Academy for Global Business Advancement, 4(1), 619-618.

Jaccard, J., Turrisi, R., \& Wan, C.K. (1990). Interaction effects in multiple regression, 72, Newsburg Park, California: SAGE Publications.

Jones, F.F., Scarpello, V., \& Bergman, T. (1999). Pay procedures - what makes them fair? Journal of Occupational and Organisation Psychology, 72(2), 129-145.

Lawler, E.E. (1971). Pay and organisational effectiveness: A psychological view. New York: McGraw-Hill.

Lawler, E.E. (1995). The new pay: A strategic approach. Compensation and Benefits Review, 14-22.

Lawler, E.E. (2000). Rewarding excellence: Pay strategies for the new-economy. San Francisco: Jossey-Bass.

Lawler, E.E., \& Hall, D.T. (1970). Relationship of job characteristics to job involvement, satisfaction, and intrinsic motivation. Journal of Applied Psychology, 54, 305-312.

Ledford, G.E., \& Hawk, E.J. (First Quarter 2000). Compensation strategy: A guide for senior managers. ACA Journal, 9(1). 28-38.

Leventhal, G.S. (1980). Fairness in social relationships. In J.T. Spence, \& R.C. (Eds.). Contemporary Topics in Social Psychology, (p.p. 211-240). Morristown, New Jersey: General Learning Press.

Mahathir Report. (1976). Report on the Cabinet Committee appointed by Cabinet to examine Royal salaries commission, Vol. I \& II on the remuneration and terms and conditions of service in the public sector. Unpublished Report, Public Services Department, Malaysia. 
Mahathir Report. (1991). Report of the special committee of the Cabinet on salaries for the public sector (a translated version). Unpublished report, Public Services Department, Malaysia.

Mani, B.G. (2002). Performance appraisal systems, productivity, and motivation: A case study, Public Personnel Management, 31(2), 141160.

Miceli, M.P., \& Lane, M.C. (1991). Antecedents of pay satisfaction: A review and extension. Personnel Resources Management, 9, 235-309.

Milkovich, G.T, \& Newman, J.M. (2008). Compensation. Boston: Irwin McGraw-Hill.

Money, R.B., \& Graham, J.L. (1999). Salesperson performance, pay and job satisfaction: Test of a model using data collected in the United States and Japan. Journal of International Business Studies, 30, 149-172.

Moorman, R.H. (1991). Relationship between organisational justice and organisational citizenship behaviors: Do fairness perceptions influence employee citizenship? Journal of Applied Psychology, 76, 845-855.

Mowday, R.T., Steers, R.M., \& Porter, L.W. (1979). The measurement of job commitment. Journal Vocational Behaviour, 14, 224-247.

Nunally, J.C., \& Bernstein, I.H. (1994). Psychometric theory. New York: McGraw- Hill.

Olson, C.A., Schwab, D.P., \& Rau, B.L. (2000, January). The effects of local market conditions on two pay-setting systems in the federal sector. Industrial and Labour Relations Review, 53(2). 272-195.

Pekeliling perkhidmatan bilangan 4 tahun (2002). Jabatan Perkhidmatan Awam Malaysia.

Pfeffer, J., \& Langton, N. (1993). The effects of wage dispersion on satisfaction, productivity, and working collaboration: Evidence from a college and university faculty. Administrative Science Quarterly, 38, 382-407.

Rajkumar, K. (1996). Paying for performance: Designing effective compensation strategies. Malaysia: Pelanduk Publications.

Robbins, T.L., Summers, T.P., Miller, J.L., \& Hendrix, W.H. (2000). Short research note using the group-value model to explain the role of noninstrumental justice in distinguishing the effects of distributive and procedural justice. Journal of Occupational and Organisational Psychology, 73, 511-518.

Sheikh Abdullah Report. (1972). Report of the commission set up to review the pay, allowances, pensions, gratuities and other terms of service of members of the Malaysian armed forces, Unpublished Report. Public Services Department, Malaysia.

Skarlicki, D. P., \& Folger, R. (1997). Retaliation in the workplace: The roles of distributive, procedural and interactional justice. Journal of Applied Psychology, 82, 434 - 443. 
Statistik IPTA. (2006). Kementerian Pengajian Tinggi Malaysia. Retrieved July 27, 2006, from http://www.mohe.gov.my/info_kpt_senarai.php ?navcode $=$ NAV004\&subcode $=$ SUB001

Sturman, M.C., \& Short, J.C. (2000). Lump-sum bonus satisfaction: Testing the construct validity of a new pay satisfaction dimension. Personnel Psychology, 53(3), 673-700.

Suffian Report. (1967). Report of the Royal Commission on the review of salaries and conditions of service in the public services. Unpublished Report, Public Services. Department Malaysia.

Sulaiman, M., \& Mamman, A. (1996). Managerial attitudes to pay system in the Malaysian public sector. Malaysian Management Review, 31(1), 29-43.

Tabachnick, B.G., \& Fidell, L.S. (2001). Using multivariate statistics. Sydney: Allyn and Bacon.

Warr, P.B., Cook, J., \& Wall, T.D. (1979). Scales for the measurement of some work attitudes and aspects of psychological well-being. Journal of Occupational Psychology, 52, 129-148.

Watson Report (1963). Report of the commission to examine the structure of the public services of Sarawak and North Borneo. Unpublished Report, Public Services Department, Malaysia.

Wong, C., Hui, C., \& Law, K.S. (1995). Causal relationships between attitudinal antecedents to Turnover. Academy of Management Journal, 342-346.

Wright, L.L. (1996). Qualitative international management research. In B.J. Punnett, \& O. Shenkar (Eds.) Handbook for International Management Research, (pp. 63-81). Oxford, UK: Blackwell Publishers. 